\title{
People's Power in Power? Hong Kong's political development and the July rally
}

\section{by Benson Wai-kwok Wong}

On 1 July 2003, most of the people in Hong Kong were not happy with celebrating the reversion of sovereignty to the People's Republic of China (PRC); instead, over 500,000 Hong Kong people no longer kept silence over Tung's six years of administering the city and actively involved in a large-scale rally. A large number of political scientists and commentaries were surprised to see the people's determination not to keep silence and to actively participate in a large-scale rally. Prior to the anti-government rally, many observers, such as pro-government political sociologist Lau Siu-kai, estimated that only 30,000 people would join the demonstration.[i] As a matter of fact, however, 1 out of 7 people joined the rally.

This article addresses a key question, namely, whether the people's power is effective in Hong Kong's recent political developments. It begins with a description of political developments in 2003, which I think are necessary to understand why the people of Hong Kong have turned their cynical and retreated mentality to an infuriating and provocative one. Finally, this article will portray the prospect of growth and development of power of the people with some reference to Hong Kong's political setting and the attitude of the PRC government towards the Hong Kong issue.

The static and distasteful atmosphere: Tung's incompetent governance since the handover

Over the past six years, Hong Kong was increasingly discontented with Tung's administration, as revealed in a telephone survey conducted by the Hong Kong Transition Project. About 51\% of respondents were satisfied with the performance in 1997; yet only $23 \%$ had the same view in November 2002 . Furthermore, Tung Chee-hwa, Chief Executive of the Hong Kong Special Administrative Region, seems to be the focus of popular discontent, as manifested in the way that only $29 \%$ of the interviewees showed their dissatisfaction in 1997. His unpopularity rose, however, to $68 \%$ in November 2002. Unfortunately, the people of Hong Kong in general think that they have no choice and say in the selection of their leaders and thus have kept silence.[ii]

However, two important issues drastically changed the mind of the people of Hong Kong. First, the outbreak of the severe acute respiratory syndrome (SARS) exposed the incompetence of the HKSAR government in terms of leadership and administration.

Second, the proposed amendments of the Article 23 of the Basic Law constituted distrust and hostility between the government and people.

\section{The Chinese pneumonia: People were saving and empowering themselves}

The SARS broke out and was handled covertly in China. The disease can be traced back to Foshan, Guangdong, where a mysterious respiratory illness broke out in November 2002.[iii] The proliferation of the unknown disease between December 2002 and February 2003 in southern China made Guangdong authorities aware of the imminent threat. However, the authorities intentionally refused to disclose information about the spread of the virus; thereby leading to the numerous rumors. For example, many people thought that herbal medicine might be efficient in the fight against the new disease. Some bought and bulkily stored rice; some even cooked vinegar and thought the smoke released would kill the virus.[iv] Unfortunately, the HKSAR government failed to get useful information through formal or informal channels from the Guangzhou authorities. 
In Hong Kong, SARS was overlooked at the beginning and the government failed to educate its citizens, which finally resulted in a severe public outcry. In early March, the government claimed that SARS would be a disease whose outbreak would be restricted to hospital areas, and the public should thus not worry about the virus. Consequently, the people of Hong Kong refrained from taking precautions to prevent the disease.[v] The situation worsened rapidly at the end of March. Mostly because of the poor leadership of Yeoh Eng-kiong, Secretary for Health, Welfare and Food:

(1) He refuted the view that SARS was widespread in the local community; (2) he openly praised the Health Department of the PRC for adopting an 'active and friendly' attitude towards the handling of SARS; (3) he and Tung Chee-hwa did not seek for any professional assistance from Beijing when Zhang Wenkang, the ex-Health Minister of the PRC visited Hong Kong in late March[vi]; (4) he could not deal with the inefficient policy for allocating the resources to hospitals[vii]; and (5) he could not settle the dispute between the University of Hong Kong and the Chinese University of Hong Kong over the repetitious medical research on the SARS.[viii]

Numerous people of Hong Kong lived under angst and turbulence, but even more chose to take action. They wore facial masks in public areas; cleaned private and public areas surrounding their residence; donated money, masks, fruits, flowers, Vitamin C pills; and sent greeting cards to the medical staff of hospitals. That all was an impressive phenomenon for the people of Hong Kong. Soon, it become clear to them that the cannot rely on the government.

In the meantime, Tung and his political comrades chose to stay behind the scene at first and eventually appeared on the front stage to demonstrate their abilities and diligence in handling the SARS crisis. Tung did not critically remark the spread of SARS until early April. Other officials kept "distance" with Yeoh and Tung throughout the case. While the number of cases decreased, the government organized the 'Clean Day' on 20 April, when Tung and key public officials cleaned public areas that had earlier been cleaned by workers of the Food and Environmental Hygiene Department.

Tung and his followers continued to boost about their contribution to the elimination of the SARS virus. On 23 June, Tung visited the Amoy Garden for 20 minutes when the World Health Organization removed Hong Kong from the infected city list, but his schedule was kept secret in order to prevent residents and recovered patients (especially those living in Block E in Amoy Garden) from staging protests against him. On 26 June, the Hospital Management and Administration Group of the SARS Expert Committee began to investigate why there had been such a large-scale outbreak of SARS in Hong Kong. Yeoh was appointed chairman and convenor of the committee-a move that let many people question the objectivity of the committee.[ix]

To sum up, the government's strategy of 'showing up merits and covering up demerits' revealed that the government wanted to save itself and intentionally ignored the mistakes made by the poor leadership and administration throughout the SARS outbreak. The discontented people were just waiting for an opportunity to express themselves in a provocative way.

\section{Article 23 of the Basic Law: the ruling elite playing with fire}

In September 2002, the HKSAR government released "Proposals to Implement Article 23 of the Basic Law Consultation Document," with the aim of enacting laws to guarantee national security. As a matter of fact, the government itself acknowledged that most of the items covered by Article 23 are already included in existing laws. Inchoate and accomplice offences of attempting, aiding and abetting, counseling and procuring the commission of substantive offences are currently covered by the common law. Law enforcement agencies are at present given sufficient powers to prevent crimes from happening. In short, under existing laws, the government has enough powers to take immediate action to protect national security without seeking any additional power. [x] 
The public expressed their worries about the law, since national security laws should be subject to wide public consultation and scrutiny by the democratically elected parliament in democratic regimes. However, the legislature in Hong Kong does not have sufficient powers and representation to check the government under the Basic Law. The power of final adjudication is at the mercy of the Standing Committee of the National People's Congress (SCNPC).[xi]

Many citizens argued that it is not an urgent task to enact the laws, since the PRC is not under any external threat. However, pro-government forces did not share this view; they advocated the necessity of legislation and adopted the following strategies to assail the divergent views:[xii]

First, they selectively accepted public opinions, emphasizing for those who supported legislation. Regina Ip, the Ex-secretary for Security, remarked that "Taxi drivers and restaurant waiters are not qualified to make suggestions over the bills." She also siad that those who opposed legislation "are emotional, irrational, subjective and negative." [xiii] She even refused to attend the seminars organized by the university's student unions, but was present at those seminars run by the 'pro-Beijing groups' supporting legislation. Hence, the government made use of the agreeing views to claim that the general public upheld legislation.

Second, they launched a series of political mobilization so as to back up legislation. With the endorsement of the Beijing authorities, all pro-Beijing groups actively expressed their views supporting legislation. The Democratic Alliance for the Betterment of Hong Kong (DAB), a leading pro-Beijing political party, played the leading role in the entire campaign. It set up the "Alliance for Supporting the Legislation to Defend the National Security" to conglomerate all leftist forces, such as folk, municipal, women, teachers, professional and kaifong (neighborhood) associations. Under the domination of the DAB in various geographical constituencies of the District Council, they voted for the passing of the proposal to implement Article 23 of the Basic Law.

Third, the government's dealing with public opinion throughout the consultation process is difficult to follow. For example, the government published the 'Compendium of Submission' after the end of the consultation. However, it adopted the inconsistent criteria for assessing affirmative and negative views: Some proposals with negative views were not included in the collection, showing that the government manipulated the process of dealing with public opinion.

Under such circumstances, the government strongly believed that it was in favorable condition throughout the whole consultation process, but it underestimated the public resentment and worries towards the proposal and consultation. In June, the Civil Human Rights Front-a voluntary organization aiming at opposing Article 23 and at political liberalization in Hong Kong - proposed that a rally be organized on July 1. In response, Regina Ip remarked that it was inevitable that most of the people were under the influence of mass promotion. She said that as July 1 was a holiday, people would take rally as a leisure activity rather than fight against Article 23.[xiv] Her remark angered many citizens, hastening the outbreak of the rally on July 1.

\section{July 1 Rally: People's Power in Expression?}

Although the outside world estimated the number of participants at half a million, the actual figure was probably more than 750,000 . Many of the marchers came from Hong Kong's normally apolitical middle class-teachers, lawyers, bankers, business executives-spurred into action by fear the new law would give the government similar powers to suppress dissents such as this had been the case in mainland China.[xv] Even policemen, firemen, and grassroots-level leftist groups came out to express their grievances.

Most participants expressed their dissatisfaction about the proposed legislation of Article 23 of the Basic Law and of Tung's governance. The protesters designed stimulating slogans and shouted them loudly across the streets of Hong Kong. Here are some of 
these:[xvi]

- (Hong Kong) has returned to China for six years; we are in bad luck for six years.

- (The government) passed Article 23 rudely; strategies used were dirty.

- We should elect our Chief Executive, regardless of the Leftists, Moderates or Rightists.

- Tung Chee-hwa is stupid, he had better sell antiques.

- Mr. C.H. Tung, step down please.

- The good news will come when Tung Chee-hwa steps down.

- Whith Tung Chee-hwa in power, the economy of Hong Kong worsened.

- Down with the Brooming Head (i.e. Regina Ip), Hong Kong would be free! Down with C.E. Tung and the pro-government dogs!

From the above slogans, we find that most Hong Kong people are discontented with the incompetence of Tung Chee-hwa and believe that the only way to save themselves is to remove Tung and to directly elect the Chief Executive. Furthermore, they also criticized the domination of pro-government politicians in the various decision-making and consultative agencies, namely the Executive, Legislative and District Councils.

On July 9, outside the Legislative Council Building, there was once again a large-scale protest with 50,000 Hong Kong residents. They requested the government to stop the deferred second reading of Article 23 legislation bill, and demanded that Tung Chee-Hua step down for pushing ahead with the passage of the National Security Bill. As a result, James Tien, a pro-government member quitted his post in the Executive Council. Regina Ip and Anthony Leung, the Secretary for Finance, resigned thereafter. On September 23, the government declared that Article 23 legislation bill has been shelved. The political crisis seemed to be released in the eyes of Tung Chee-hwa. In retrospect, is it meant that people's power is triumph?

\section{Conclusion: A rough road ahead}

The July demonstration was indeed impressive and historical in nature. Nevertheless, the Beijing government and pro-government circles have tried to divert the political grievances by interpreting the nature of demonstration as the result of the current economic situation. Zeng Xianghong told pro-Beijing Hong Kong intellectuals that middle-class participation in the rally reflected that economic problems and 'negative capital' are two major sources of the middle class's discontent.[xvii] In fact, both Beijing and the HKSAR government have emphasized the economic factor, with the aim of averting any political reforms, such as the dismissal of Tung Chee-hwa, the direct election of the Chief Executive, the inauguration of constitutional review and the restructuring of the unrepresentative Executive and Legislative Councils.

Benson Wai-kwok Wong is a Ph.D. candidate at the Department of Politics and Public Administration, the University of Hong Kong.

[i] Ming Pao, 10 June 2003, p. A-15. Lau was co-opted to be the Head of the Central Policy Unit, the HKSAR government, on 1st July 2002, and was responsible for advising on specific policy issues at the request of the Chief Executive, the Chief Secretary for Administration or the Financial Secretary, and for overseeing the annual Policy Address exercise. For details, see the website of the Central Policy Unit at http://www.info.gov.hk/cpu. 
and Freedom of Press in Hong Kong. Hong Kong: Hong Kong Transition Project, December 2002, pp. 84-86. The report can be read and downloaded at http://www.hkbu.edu.hk/ hktp.

[iii] Ping-Chung Leung and Eng-Eong Ooi ed., SARS War: Combating the Disease. New Jersey: World Scientific, 2003, pp. 17-18.

[iv] Benson Wai-Kwok Wong: "'Covering up the Epidemic Situation - Turning A Natural Disaster to the Human Chaos", Hong Kong Economic Times, 13 June 2003, p. A33 (in Chinese). I browsed the major websites of mainland Chinese newspapers between February and March and found that no reporting on the SARS case.

[v] Anthony Bing-leung Cheung, "Inspirations of the SARS on Public Administration", in Chi-kwan Ho ed., Inspirations from the SARS - A Careful and Atypical Observation of Hong Kong Society. Hong Kong: Step Forward Multimedia, 2003, p. 20 (in Chinese).

[vi] Zhang Wenkang was removed from his post on 20 April 2003, possibly because he made no efforts in preventing the widespread of the SARS in Beijing and adopted the covert manner in releasing the SARS news to the international media, thereby damaging the image of the PRC government. See 'The Central Committee of the PRC removed Zhang Wenkang from the post of the party secretary, Department of Health', sina.com.cn, http://news.sina.com.cn/c/2003-04-20/174197616s.shtml (in Chinese).

[vii] For example, many nurses and medical staff voiced out their worries in "Teacup in the Storm", a popular phone-in radio program produced by the Commercial Radio of Hong Kong, and severely criticized some senior administrators did not permit them to take any precautious measures to protect themselves. For details, browse the website at http://pshweb01.881903.com/main/event/ap/index.htm (in Cantonese).

[viii] Benson Wai-kwok Wong, 'Tung's 'Dream Team' is working in the dreaming environment", Hong Kong Economic Times, 2 May 2003, p. C22 (in Chinese).

[ix] 'Hospital group of SARS Expert Committee starts three-day meeting', HKSAR Government Press Release, (http://www.info.gov.hk/gia/general/200306 /26/0626130.htm), 26 June 2003.

$[\mathrm{X}]$ 'FAQ on Article 23', http://www.article23.org.hk/english/main.htm.

[xi] Ibid.

[xii] "The Consultation of the Legislation of the Basic Law Article 23 - The government turns the Masses into the Enemies", Hong Kong Economic Times, 2 July 2003, p. A27 (in Chinese).

[xiii] 'The Collection of Mrs. Ip's remarks', http://www.article23.org.hk/chinese/main.htm.

[xiv] Ibid.

$[x v]$ 'Huge Protest Fills Hong Kong Streets', CNN.com, http://edition.cnn.com /2003/WORLD/asiapcf/east/07/01/hk.protest/index.html

[xvi] See Ah Pink and Lao Fuqian, Chaos of Chee-hwa. Hong Kong: Sibixiang, 2003.

[xvii] Sing Tao Daily, 9 September 2003. In addition, Kuan Hsin-chi, a local political scientist, also shared the same view and said that the July 1 Rally should not be attributed to Tung's incompetent governance, but to the fact that government adopted the hard-line approach to promote the policy, harming the interest of the certain social group. Metro News (Hong Kong), July 4, 2003, p. 2. In fact, Kuan is serving as a part-time member of the Central Policy Unit. During the period August 2002 to July 2003, he was appointed to be Panel on Social Cohesion under the Central Policy Unit. 
East Asia.at - Online Journal of the Austrian Association of East Asian Studies

(C) 2003 by Austrian Association of East Asian Studies 